\title{
Improving VIII Grade Students' Mathematical Problem Solving Ability Through Realistic Mathematics Education
}

\author{
I Made Ari Purwadi \\ SMP Laboratorium Undiksha Singaraja, Indonesia
}

\begin{abstract}
This paper aims to describe the improvement of students' mathematical problem solving (MPS) ability on the topic of simultaneous linear equations system through Realistic Mathematics Education (RME). Nineteen students of VIII grade in SMP Laboratorium Undiksha in the first semester of the academic year 2019/2020 participated as the research subject. This classroom action research consists of three cycles and every cycle contains three meetings. The data was collected by observation and essay-test before being analysed using descriptive statistics. The finding is that the average score of the students' MPS ability increased from 71,92 in the first cycle, to 73,2 in the second cycle, and to 75 in the third cycle. As demonstrated, the implementation of RME could increase students' MPS ability. Hence, the implementation of RME has made students more motivated, more active during discussion and learning process, solve problems more easily, and communicate their understanding better.
\end{abstract}

Keywords: RME, mathematics, problem solving.

\section{Introduction}

Mathematics is an important part of civilization and possesses vital role in the development of science, engineering, and technology. Aside from that, mathematics is also crucial in nurturing competent workforce. Therefore, education system should put mathematics as one of the top priorities and ensure that every child will learn it.

Problem solving is one of the skills that can be nurtured through mathematics. National Council of Teachers of Mathematics (NCTM) lists five process standards in mathematics; one of them is problem solving. In addition, to enhance the quality of education and human resources, Indonesian government through the Curriculum 2013 put emphasize on the development of $21^{\text {st }}$ Century's skill, which includes problem-solving (Kemendikbud, 2018; Phonsa et al., 2019; Tican \& Deniz, 2019). Problem-solving is a higher-order thinking skill because it applies to multiple skills and should be learned by the students during the process of learning (Demitra \& Sarjoko, 2018). If the students want to be a successful problem solver, they need to deeply understand the strategies and techniques of problem solving (Marchis, 2013). Furthermore, they also have to be able to think logically, analytically, systematically, critically, and creatively (Surya \& Putri, 2016).

Problem solving requires students to engage in a problem which solution method is not obvious, thus demanding them to choose and use appropriate knowledge (NCTM, 2000). Unfortunately, reality shows that many students are currently struggling to solve mathematical problems (Hendriana et al., 2018). For the students participating in this study, their mathematics achievement during the past year has not met the curriculum requirement, 
specifically to achieve 70 for the minimum score of mastery criteria. This situation demonstrates the lack of the students' problem solving ability (Hendriana et al., 2018; Surya et al., 2016).

Based on the preceding problem, using an innovative learning approach will help the students to minimize any problem they may have about mathematics problem solving on the topic of simultaneous linear equations system. Therefore, selecting a learning approach which allows the students to construct their knowledge through their explorations on social and mathematics phenomena is the right way to do. One of the innovative strategies which can be applied in the mathematics classroom is the Realistic Mathematics Education (RME) approach.

RME was initiated in 1971 as part of Wiskobas (primary mathematics) project in the Netherlands (Treffers, 1993). Hans Freudenthal, one of the key people of the project, was a firm believer that mathematics is a part of human activity (Treffers, 1993). It must be connected to reality, stay close to the students, and should be relevant to the society (Hadi, 2020; Julie et al., 2014; Yet et al., 2017).

The main characteristic of RME is the central role of rich and realistic problem situation (Van den Heuvel-Panhuizen \& Drijvers, 2014). These situations elicit the emergence of mathematical concepts in the beginning of the lesson, and in the end of the lesson, become the context in which the students can apply their freshly acquired knowledge. RME emphasizes the students' exploration and starting from the real world in the process to develop mathematical understanding (Hadi, 2020).

Van den Heuvel-Panhuizen (in Hadi, 2020) further stated that the students should learn mathematics by applying the mathematical concept in daily-life situations which make sense to them. It means the context must be meaningful and problems have to be imaginable, hence the word "realistic" in RME. Students have to be allowed to reinvent mathematics concepts by doing it in the process of learning (Ardiyani et al., 2018; Fauzi \& Waluya, 2018; Yet et al., 2017). Thus, the role of the teacher in RME learning is as a facilitator who can establish the link between students' world to the world of mathematics.

Following the explanation above, some researches showed that RME is effective in learning mathematics. First, research by Widyastuti and Pujiastuti (2014) found that RME is effective to enhance the students' mathematical conceptual understanding and disposition. Second, research by Yet et al. (2017) concluded that RME has a positive influence on the students' mathematics self-report. Third, research by Arsaythamby and Zubainur (2014) revealed that RME is effective to help the students increase their learning activities. Fourth, research by Fauzi and Waluya (2018) reported that RME has good effects in developing the students' mathematical communication. Fifth, research by Idris and Silalahi (2016) concluded that RME can improve the elementary school students' ability in solving contextual problems.

Based on the aforementioned fact, the author considers it important to investigate learning approach that might be able to increase the students' mathematical problem solving. This article aims to describe RME in the context of junior high school mathematics classroom in Indonesia and how it affects the students' mathematical problem solving. The research question to be answered in this paper is how does RME affect junior high school students' mathematical problem solving (MPS) ability? 


\section{Methods}

This classroom action research conducted at SMP Laboratorium Undiksha in the first semester of the academic year 2019/2020. Nineteen seventh grade students participated in this study. The research method employed here is action research. In action research, teacher pairs practical teaching implementation with a research procedure, as a personal attempt to understand classroom phenomenon while being involved in the process (Hopkins, 2008). It is conducted to improve the mathematics learning quality especially to the system, work methods, processes, content, and classroom learning situations/atmosphere (Ni'mah, 2017). This research consists of three cycles with four phases in each cycle namely planning, implementation, observation, and evaluation or reflection (Djajadi, 2019).

The detailed activities of each phase are described as follows:

\section{Planning}

After identifying the problem and initial reflection was carried out, the researcher compiled the action plan which consists of; (1) designing learning scenario and tool (lesson plans and worksheets), (2) developing instruments (validation sheets, observation sheets, problem-solving test); (3) preparing media and teaching aids; and (4) validating instruments.

\section{Implementation}

The activities in the implementation phase were as follows; (1) implementing the action plan; (2) examining the learning trajectory, and (3) improving or enriching the learning process. There are three meetings in this phase.

\section{Observation and Data Collection}

This phase was conducted at the same time as implementation phase. The observer used observation sheets as a guide. Furthermore, the data on the students' mathematics problem solving ability was also collected through an essay test.

\section{Evaluation-Reflection}

The evaluation and reflection were conducted on each cycle. The reflection was used as a basis for planning the next phase.

The data collected in this study consist of the learning process and students' mathematics problem solving ability. These data were collected through observation sheets and essay tests. The questions in the MPS test use real-life contexts and there is no obvious clue on mathematics concepts needed to solve it. The learning process data were selected for relevant details and described in relation to the research question. The data for the students' mathematics problem solving ability were analysed using descriptive statistics.

\section{Results and Discussion}

Firstly, the researcher prepared the lesson plans and worksheets for nine meetings (three meetings for each cycle). The lesson plans, worksheets, and tests are designed according to RME approach. All of them designed for guiding students to find the mathematics concept independently and the teacher just being a facilitator. 
There are three RME principles that was used as a reference by the researcher in designing the lesson plans and worksheets, namely: 1) guided reinvention through mathematization, 2) didactical phenomenology, and 3) emergent modelling. These principles manifest themselves in the worksheet through 1) use of phenomenological exploration or contexts, 2) the use of model, and 3) intertwining of various learning strands (Hadi, 2020).

The learning material employs local-cultural contexts which are experientially real to students and does not contain information on how to use the formula directly. The activity designed by the teacher also have to engage students in the discussion process (Putri et al., 2015). The teacher also applied the classroom socio-norms. The teacher emphases that the communication occurred not only between teacher and students but also among the students. Teacher 's role to explain the context or problem or concept are minimal and the students are given more chance to explain and answer the question. In other hand, the students had to be active in the learning process.

Secondly, the researcher conducted a preliminary test to determine the students' initial ability on problem solving. The researcher analysed the test result by statistics descriptive. The researcher used minimum completeness criteria of 70 in reference to the 2013 curriculum. Based on the test, the highest score was 79, while the lowest was 40. According to the completeness criteria, ten students did not meet the target score and nine students did. The average score was 65,5 . The research result in every cycle is as follows.

\section{First cycle}

The first cycle of this research was done in three meetings and it began with learning about how to make mathematical model of a context. At the beginning of the learning, the teacher instructed students to make five groups and stimulated them to recall the concept of algebra as the pre-requisite knowledge. Teacher started the discussion by showing a context, followed by the students' discussion about how to transform the real word problem into a model with mathematical symbol. The following is a context that was displayed by the teacher: "The price of 4 pencils and 5 notebooks is IDR 23,000, while the price of 2 pencils and 3 notebooks with the same type is IDR 13,000. Make the mathematics model and what is the price of one notebook"

The following is a brief segment illustrating Group 1 discussion:

Student 1 : (S1 makes the model by drawing 4 pencils and 5 notebook)

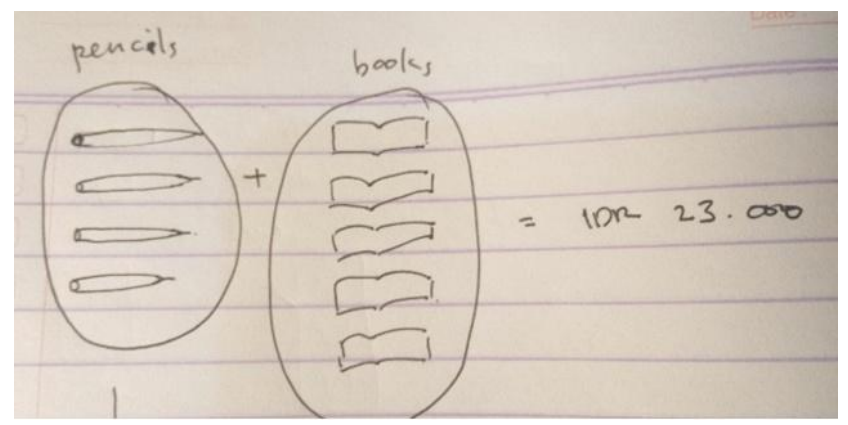

Figure 1. Strategy of Student 1 by using pictorial. 
Students 2 : Why don't you consider the pencil is " $p$ " or " $a$ " or " $x$ "? It makes them simpler, like mine. Do you remember what we learn in algebra class? You can assume the unknown thing by variable.

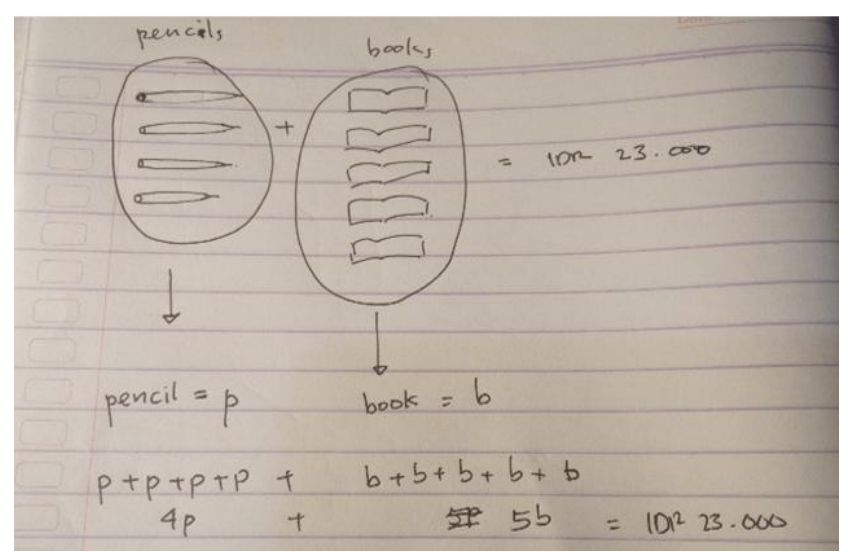

Figure 2. Suggestion from Student 2.

Student 1 : Wait, I'm confused, I think it will be easier if I draw the question. I want to guess the price of this pencil by the real price in the market. Yesterday, I bought my pencil IDR 2.500 and I think I must try and guess until get IDR 23.000. (thinking)

Student 2 : Well, this is mine (S2 shows his work)

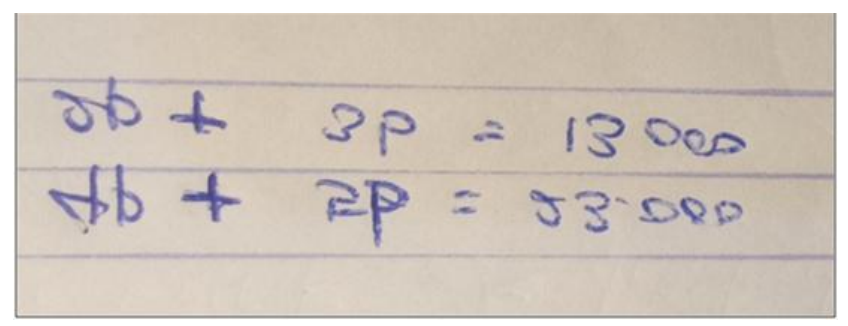

Figure 3. Mathematics model of Students 2.

Student 1 : (After 10 minutes) I give up, I can't find the appropriate price. I will try to do it like you.

Student 2 : Yeeahhh, I got it, ( $S 2$ gets the model " $4 p+5 b=23.000$ and $2 p+3 b=$ 13.000").

Student 3 : Why don't you use pencil $=x$ and book $=y$ ?

Student 2 : Ya, it is variable, you can use other alphabets.

Student 1 : I changed my model, Okay, done!!! We get $4 p+5 b=23.000$ and $2 p+3 b=$ 13.000 with $\mathrm{p}=$ price of one pencil and $\mathrm{b}=$ the price of one notebook.

Student 1 : Mr. Ari, are we correct? (show the model to the teacher)

Teacher : Hmmm, great job, we will discuss with other groups soon. 
Student 2 : Now, we must get the price of one pencil. Wait, I will look at the example. I learned this material last night. We can use elimination method?

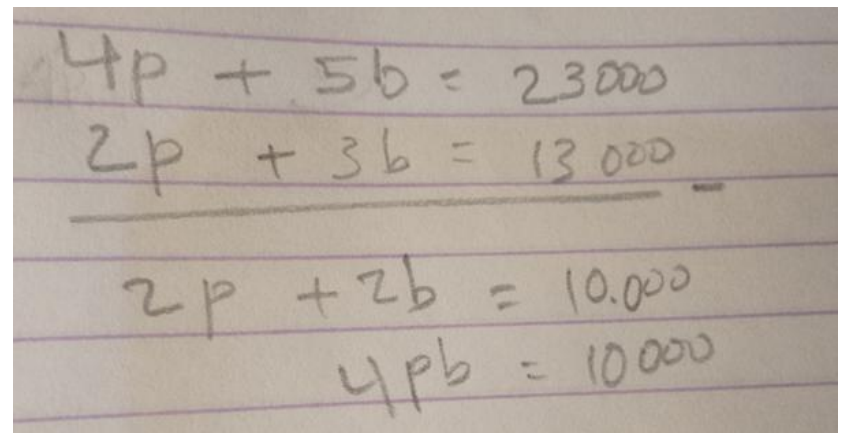

Figure 4. Work of Students 2

Teacher : Are you sure? Check it again!

Student 2 : Wait Sir, (write the solution)

Student 3 : I found the price of one notebook (show her work)

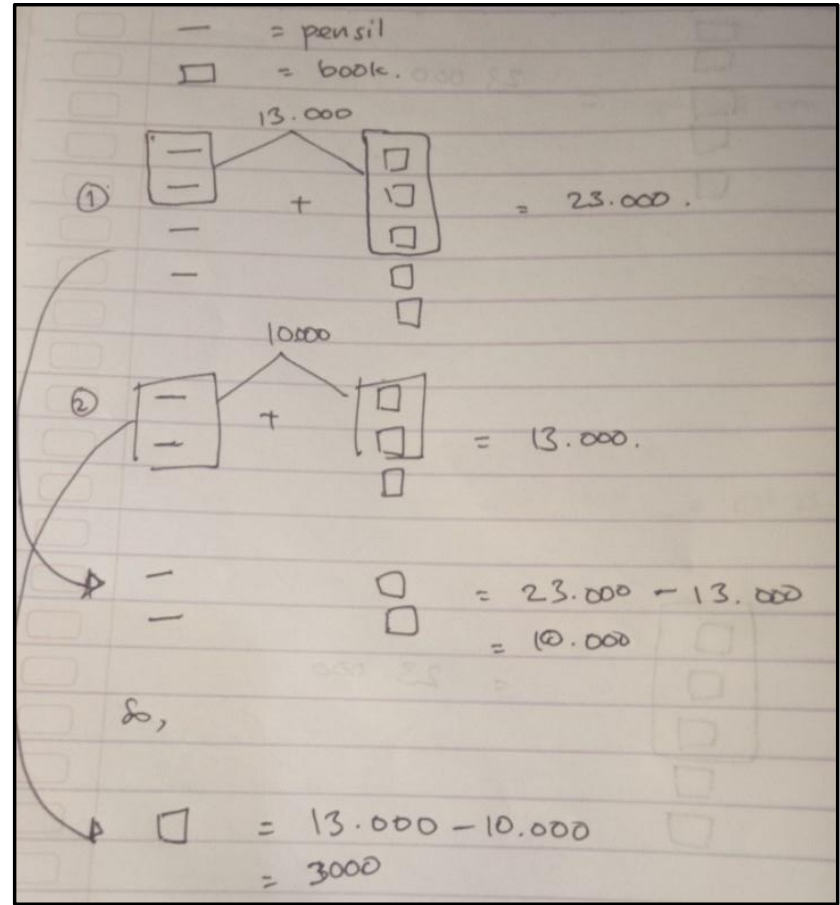

Figure 5. Strategy (pictorial) belong to Student 3

Student 2 : Woo, great idea.

Teacher : Excellent, how if you change into mathematics symbol?

Student 3 : Ya Sir, I will try.

Student 3 : (15 minutes later, S3 shows the work) 


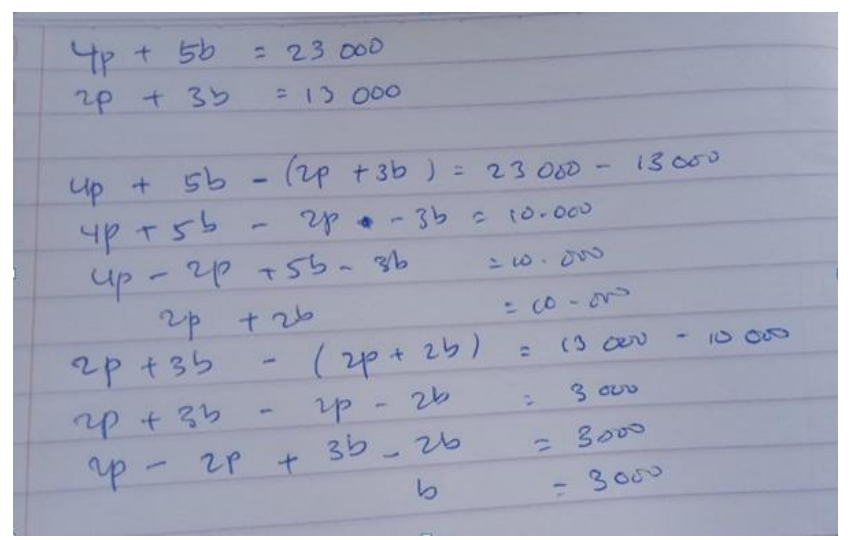

Figure 6. Student 3's work (symbolic).

Students refined and adjusted the models. The teacher observed that the students can make various and different models. In the next meeting, they learned how to formulate the mathematical model until generalizing. Lastly, students determine the value of variables without inducing the techniques.

The example of the question in the MPS test of the first cycle is as follows.

"Hadi buys 7 cups of coffee and 4 pieces of toast with the cost is IDR

51.000 and Budi buys 5 cups of coffee and 4 pieces of toast with the cost is

IDR 41.000. Find the cost for each item."

Figure 7 showed the sample of student's answer.

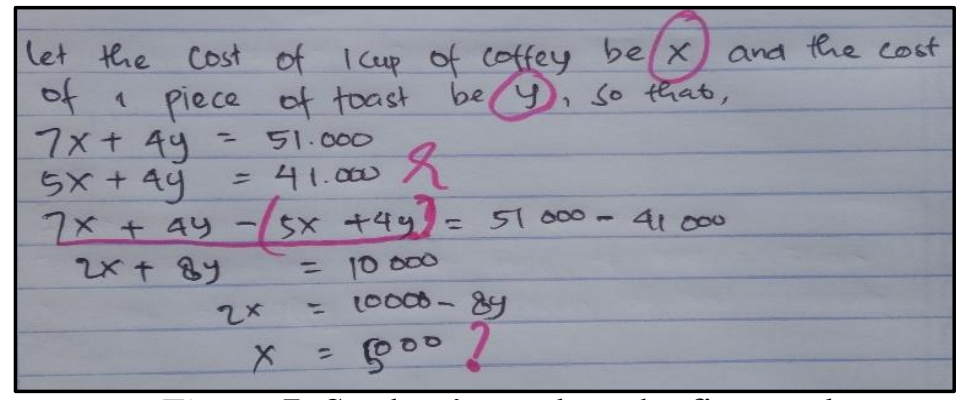

Figure 7. Student's work at the first cycle.

The highest score of the test was 90, while the lowest was 56. Seven students (37\%) did not meet the target score, while 12 students (63\%) did. The average score was 71.92 . This score increased from the preliminary test. The first cycle's reflection reveals several problems in carrying out the lesson as follows; (1) only a few students participated in discussion, (2) the students needed a lot of teacher's guidance, (3) the high-ability students dominated the discussion, (4) some students were still shy and reluctant to offer their comments and suggestions, as well as (5) the scaffolding from peers did not optimally run.

Based on the reflections, to enhance the learning quality in the second cycle, the researcher made some improvement by (1) evaluating the learning context and problem by redesigning problems to be more familiar with the students, (2) requiring all students to engage in discussions and giving rewards to the most active groups and students, (3) asking the students who assist their friend not to give the whole information at the beginning but 
only tried to help by giving the necessary clue, and (4) at the end of the meeting, the students were encouraged to reflect and make conclusion.

\section{Second cycle}

The second cycle began from introducing elimination technique for solving system of linear equation with two variables. It started from elimination because in the first cycle, the students can find the ways to eliminate and subtracted one variable on the model. Teacher redeveloped the worksheet in order to make students can understand the concept easily. Students discussed their model and the plan of solution with other students. After that they refined and adjusted until found the solution. The teacher observed that some students can make unique ways to find the steps of elimination technique. The teacher shows the picture on the slide and students are instructed to get the price of one umbrella and one cap.

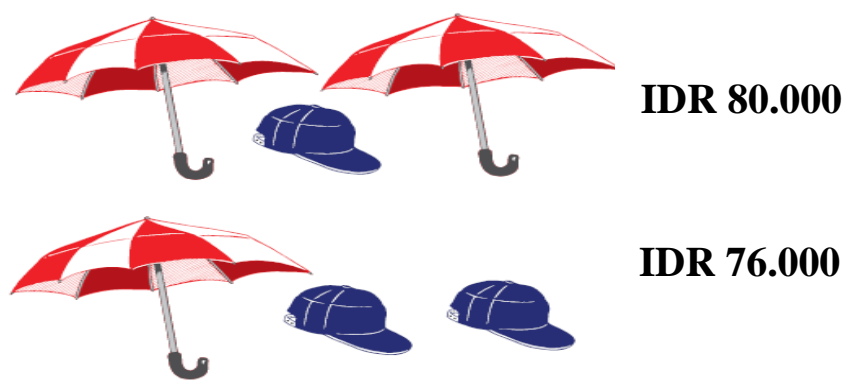

Figure 8. First context at the $5^{\text {th }}$ meeting (modified from Holt, 2006).

The following is a brief segment that illustrates a discussion in Group 2:

Student 5 : Eliminating in Bahasa is "menghilangkan", so we have to eliminate one variable on the equation.

Student 6 : It is similar with how to get the price of the notebook that we learned last week, yes?

Student 5 : Okay, I will try to change the pattern. At the first line there are two umbrellas and a cap but in the second line there are one umbrella and two caps. When the umbrella in the first line change by one cap the price will decrease 4.000 to be 76.000 . So that, if the pattern is continued, we will get 3 caps with price $76.000-4.000=72.000$. Then a cap is 24.000 .

Teacher : Excellent, other students have other opinion?

Student 6 : If the first line is changed to 3 umbrellas it will equal to 84.000 , thus the price of an umbrella is 28.000 .

Here is the example of the question in the MPS test of second cycle.

"The sum of two numbers is 36 and their difference is 9. Find the two number." 
Figure 9 showed the sample of student's answer.

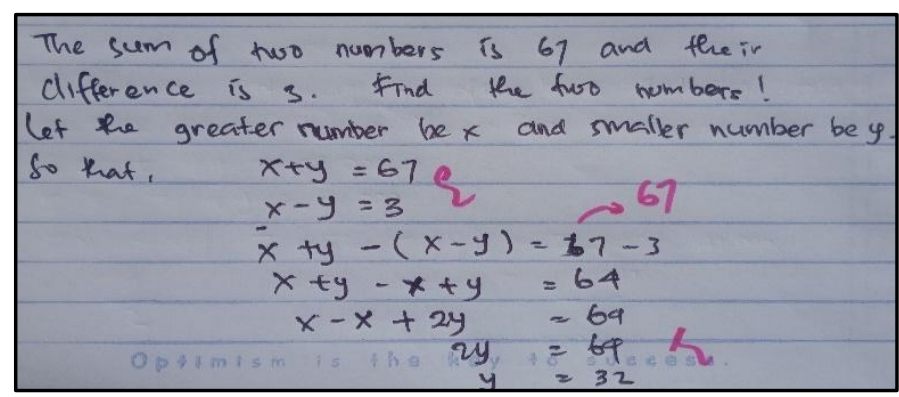

Figure 9. Student's work at the second cycle.

The highest score of the test in the second cycle was 78, while the lowest was 42 . Four students $(21 \%)$ did not meet the target score, while 15 students $(79 \%)$ did. The average score of students' MPS was 73,2. The average score increased 1,77\% from the previous cycle. The highest score achieved was significantly smaller than the first cycle, more students met the target score.

Several problems were identified during the reflection namely (1) the high-ability students still dominate the discussion; and (2) the scaffolding from the peers did not run optimally. These problems were taken into consideration during the refinement of the learning activity, which includes (1) allowing the passive students to present their work in front of the class; and (2) emphasizing to assist students only by providing clues to solve the problem.

\section{Third cycle}

The third cycle also conducted in 3 meetings and it began by an introduction to the substitution technique. The topic of discussion was mixed (elimination and substitution) technique for solving system of linear equation with two variables. Teacher instructed the students to recall the value of function and how to enter the element of domain to the function to obtain the range. The lesson started with the following problem "two t-shirts cost IDR 200.000 , one $t$-shirt and one trouser cost IDR 400.000. Find the cost of each item". The following is a brief segment that illustrates a common response:

Student 9 : Ah I see, I buy $2 \mathrm{t}$-shirts and equals IDR 200.000 so one of them is equal to IDR 100.000 (thinking).

Teacher : All right, then?

Student 9 : Let's change the price of one t-shirt into the second model. Aha, I got it. One of it 100.000 so we can write $100.000+$ trouser $=400.000$. Yes, one trouser equal to 300.000 .

Teacher : Excellent, other students have another opinion? Or similar ways?

Teacher : Anybody know the synonym of "change"?

Student 10 : Yes, change is equal to substitute.

Teacher : Right, we can use it to determine the price of the item.

In the third meeting the students applied the mix method to solve problems. Here is the example of the question in the third cycle MPS test. "The sum of two numbers is 36 and 
their difference is 9. Find the two number." Figure 10 showed the sample of student's answer.

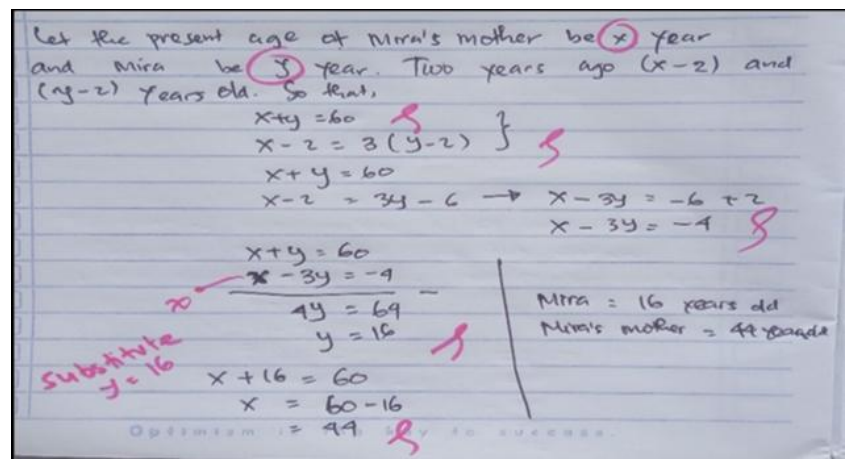

Figure 10. Student's work at the third cycle.

The highest score of the test in the second cycle was 100, while the lowest was 45 . Two students (21\%) did not meet the target score, while 17 students (79\%) did. The average score of students' MPS was 75 . The average score increased 2,45\% from the previous cycle. The highest score achieved was significantly higher than the second cycle and the number of students who met the target score increased. The finding suggests that the students' mathematical problem solving ability increased throughout the cycles. This finding is relevant to Widyastuti and Pujiastuti (2014) which revealed learning with RME can improve fifth-grade students' ability to understand mathematics concepts and logical thinking. Saleh et al. (2017) also stated that RME can improve students' mathematical reasoning ability.

Furthermore, the students' engagement during classroom activity also increased. This finding can be attributed to the use of contextual problems, which is in line with the reality principle of RME (Van den Heuvel-Panhuizen \& Drijvers, 2014). The learning activities designed in this study was consistently started by presenting contextual problems to the students, which are familiar to the students and relevant to the society they live in. Contextual problems help fostering an idea that mathematics is close to real life and useful for solving daily life problems (De Lange, 1987). This understanding can motivate students to learn mathematics. Purwadi et al. (2019) also revealed that learning mathematics by presenting problems and real objects will make students feel that mathematics is useful.

Besides, learning also emphasizes understanding the processes rather than learning algorithms. At the beginning of learning, the teacher provided students with realistic problems and then allowing them to understand the problems and the context clearly. The student attempted to describe to others the problem in their own words based on their understanding. Students can use various models such as tables, charts, pictorial or visual images, and Cartesian coordinates in solving the problem. This is in line with the activity principle of RME, which states that students should be active participants of the learning process and in-charge of their own understanding (Van den Heuvel-Panhuizen \& Drijvers, 2014). Afterward, the teacher led students to discuss their different strategies that culminates in a single solution. Furthermore, the teacher also provided the students with hands-on activity with real objects. It made students more engaged in learning activities. Widyastuti \& Pujiastuti (2014) also revealed that through RME students will better see mathematics as an effort to solve daily problems thus it can attract the students' interest and motivation to learn math. 
In addition, the researcher also observed the importance of selecting problems or contexts that evoke the students' interest and engage them in the learning process. In this initial stage, researchers try to provide non-routine problems of shopping and selecting items to buy in a supermarket or store. It is important to remember that the problems must be in the student's zone of proximal development (Vygotsky, 1978, p. 86). Meaning, the problems are difficult enough that they cannot solve them easily with their prerequisite knowledge and thus, push them to devise new strategy and develop new knowledge, but not too difficult such a way that it causes frustration and despair.

\section{Conclusion}

Based on the results and discussion above, it can be concluded that the students' MPS ability and engagement increase with RME activities. However, students' MPS abilities were not yet optimal since the average score of students' MPS was still lower than 80. This research is expected to provide a good practice in the application of RME to improve students' MPS ability. The author also hopes to contribute to the achievement of educational goals and enrich the results of existing research. In order to get optimal results, the future research needs collaboration with other learning tools or media because creative and innovative learning is very important to support the success of learning. The limitation of this study is the small number of participants and the specific context. The findings here may not be generalizable nationwide, however cities and provinces with similar characteristics may obtain similar result.

\section{References}

Ardiyani, S. M., Gunarhadi, G., \& Riyadi, R. (2018). Realistic Mathematics Education in Cooperative Learning Viewed from Learning Activity. Journal on Mathematics Education, 9(2), 301-310. https://doi.org/10.22342/jme.9.2.5392.301-310

Arsaythamby, V., \& Zubainur, C. M. (2014). How a Realistic Mathematics Educational Approach Affect Students' Activities in Primary Schools? Procedia - Social and

Behavioral Sciences, 159, 309-313. https://doi.org/10.1016/j.sbspro.2014.12.378

De Lange, J. (1987). Mathematics, insight, and meaning. Utrecht: OW \& OC, Rijksuniversiteit Utrecht.

Djajadi, M. (2019). Penelitian Tindakan Kelas (Classroom Action Research).

Demitra, \& Sarjoko. (2018). Effects of Handep Cooperative Learning Based on Indigenous Knowledge on Mathematical Problem Solving Skill. International Journal of Instruction, 11(2), 103-114. https://doi.org/10.12973/iji.2018.1128a

Fauzi, A., \& Waluya, S. B. (2018). Math Learning with Realistic Mathematics Education Approach (RME) Based on Open Source-Ended to Improve Mathematic Communication. 8.

Hadi, S. (2020). Introduction to Realistic Mathematics Education. In Learning Materials of Course on Southeast Asia Realistic Mathematics Education for Junior High School Mathematics Teacher (pp. 1-8). SEAMEO QITEP in Mathematics. 
Hendriana, H., Johanto, T., \& Sumarmo, U. (2018). The Role of Problem-Based Learning to Improve Students' Mathematical Problem-Solving Ability and Self Confidence. Journal on Mathematics Education, 9(2), 291-300. https://doi.org/10.22342/jme.9.2.5394.291-300

Holt, R., and Winston, Inc. (2006). Comparing Quantities. Mathematics in Context. Level 1. Encyclopaedia Britannica, Inc. ; Holt, Rinehart, and Winston.

Hopkins, D. (2008). A Teacher's Guide to Classroom Research Fourth Edition. Berkshire: Open University Press. https://doi.org/10.1080/13674580300200452

Idris, I., \& Silalahi, D. K. (2016). Penerapan Pendekatan Pendidikan Matematika Realistik Indonesia (PMRI) untuk Meningkatkan Kemampuan Penyelesaian Soal Cerita pada Kelas VII A SMP UTY. 1(1), 10.

Julie, H., Suwarsono, St., \& Juniati, D. (2014). Understanding Profile from The Philosophy, Principles, and Characteristics of RME. Journal on Mathematics Education, 5(2). https://doi.org/10.22342/jme.5.2.1499.148-159

Kemendikbud. (2018). Peraturan Menteri Pendidikan dan Kebudayaan Republik Indonesia Nomor 37 Tahun 2018 tentang Perubahan atas Peraturan Menteri Pendidikan dan Kebudayaan Republik Indonesia Nomor 24 Tahun 2016 tentang Kompetensi Inti dan Kompetensi Dasar Pelajaran.

Marchis, I. (2013). Future Primary and Preschool Pedagogy Specialization Students' Mathematical Problem Solving Competency. Acta Didactica Napocencia, 6(2), 6.

NCTM (Ed.). (2000). Principles and standards for school mathematics. National Council of Teachers of Mathematics.

Ni'mah, Z. A. (2017). Urgensi Penelitian Tindakan Kelas Bagi Peningkatan Profesionalitas Guru Antara Cita dan Fakta. 15(2), 22.

Phonsa, K., Sroinam, S., \& Phongphinyo, P. (2019). Strategies for Developing the 21st Century Skills of School Principals under Loei Primary Educational Service Area Office. Asian Journal of Education and Training, 5(1), 198-206. https://doi.org/10.20448/journal.522.2019.51.198.206

Purwadi, I. M. A., Sudiarta, I. G. P., \& Suparta, I. N. (2019). The Effect of ConcretePictorial-Abstract Strategy toward Students' Mathematical Conceptual Understanding and Mathematical Representation on Fractions. International Journal of Instruction, 12(1), 1113-1126. https://doi.org/10.29333/iji.2019.12171a

Putri, R. I. I., Dolk, M., \& Zulkardi, Z. (2015). Professional Development of PMRI Teachers for Introducing Social Norms. Journal on Mathematics Education, 6(1), 11-19. https://doi.org/10.22342/jme.6.1.1900.11-19

Saleh, M., Prahmana, R. C. I., Isa, M., \& Murni, M. (2017). Improving the Reasoning Ability of Elementary School Student through the Indonesian Realistic Mathematics Education. Journal on Mathematics Education, 9(1). https://doi.org/10.22342/jme.9.1.5049.41-54

Surya, E., Putri, F. A., \& Mukhtar, M. (2016). Improving Mathematical Problem-Solving Ability and Self-Confidence of High School Students Through Contextual Learning Model. Journal on Mathematics Education, 8(1). https://doi.org/10.22342/jme.8.1.3324.85-94 
Tican, C., \& Deniz, S. (2019). Pre-service Teachers' Opinions about the Use of 21 st Century Learner and 21st Century Teacher Skills. European Journal of Educational Research, 8(1). https://doi.org/10.12973/eu-jer.8.1.181

Treffers, A. (1993). Wiskobas and Freudenthal realistic mathematics education. Educational Studies in Mathematics, 25(1-2), 89-108. https://doi.org/10.1007/BF01274104

Van den Heuvel-Panhuizen, M., \& Drijvers, P. (2014). Realistic Mathematics Education. In Encyclopedia of Mathematics Education (pp. 521-525). https://doi.org/10.1007/97894-007-4978-8_170

Widyastuti, N. S., \& Pujiastuti, P. (2014). Pengaruh Pendidikan Matematika Realistik Indonesia (PMRI) Terhadap Pemahaman Konsep dan Berpikir Logis Siswa. Jurnal Prima Edukasia, 2(2), 183. https://doi.org/10.21831/jpe.v2i2.2718

Yet, S., Karaca, M., \& Özkaya, A. (2017). The Effects of Realistic Mathematics Education on Students' Math Self Reports in Fifth Grades Mathematics Course. International Journal of Curriculum and Instruction, 9(1), 23. 
Improving VIII Grade Students' Mathematical Problem

Solving Ability Through Realistic Mathematics Education 